\title{
POLIMORFISME GEN ALPHA ACTININ-3 (ACTN 3) BERHUBUNGAN DENGAN MUSCLE PERFOMANCE ATLET
}

\author{
Nila Wahyuni \\ Departemen Ilmu Faal Fakultas Kedokteran Universitas Udayana \\ Jalan P.B.Sudirman, Denpasar, Bali, Indonesia \\ e-mail:wahyuninila08@unud.ac.id
}

\begin{abstract}
ABSTRAK
Pendahuluan: Performa atlet profesional merupakan hal yang sangat penting untuk pencapaian prestasi atlet. Performa atlet dipengaruhi oleh berbagai faktor yaitu faktor lingkungan seperti pelatihan, diet dan sosiokultural. Salah satu faktor penting yang juga mempengaruhi performa atlet adalah faktor genetik yang saat ini banyak diteliti. Salah satu faktor genetik yang diyakini berperan dalam performa atlet adalah gen Alpha Actinin-3 (ACTN 3). Tujuan Penelitian : untuk mengkaji bagaimana polimorfisme gen Alpha Actinin-3 (ACTN 3) menyebabkan terjadinya variasi antar individu pada muscle performance atlet. Metode : literatur studi. Hasil : Gen ACTN 3 mengkode protein $\alpha$-actinin-3 yang berperan dalam menghasilkan kekuatan kontraksi otot yang besar dan singkat (rapid forceful contraction). Variasi genetik gen ACTN 3 menyebabkan beberapa varian dari gen ACTN 3 yang berperan pada muscle performance atlet.
\end{abstract}

Kata kunci : Polimorfisme, Gen ACTN 3, Muscle performance.

\section{ALPHA ACTININ-3 (ACTN 3) POLYMORPHISM RELATED TO ATHLETE MUSCLE PERFOMANCE}

\begin{abstract}
Background: The performance of professional athletes is very important for the achievement of athletes. The athlete's performance is influenced by various factors, namely environmental factors such as training, diet and sociocultural. One important factor that also affects the performance of athletes is genetic factor that are currently being studied. One of the genetic factors believed to play a role in athlete's performance is the Alpha Actinin-3 gene (ACTN 3). Purpose : to examine how the Alpha Actinin-3 (ACTN 3) gene polymorphism causes variation among individuals in athletic muscle performance. Method : study literature. Result : The ACTN 3 gene codes for the $\alpha$-actinin3 protein which plays a role in producing a large force of contraction (rapid forceful contraction). The genetic variation of the ACTN 3 gene causes several variants of the ACTN 3 gene that play a role in the athlete's muscle performance.

Keywords: Polymorphism, ACTN Gen 3, Muscle performance.
\end{abstract}




\section{PENDAHULUAN}

Muscle perfomance merupakan salah satu komponen yang berperan dalam performa atlet secara keseluruhan ${ }^{1}$. Faktor lingkungan dan faktor genetik mempengaruhi fungsi otot, menyebabkan perbedaan yang besar pada fenotip performa fisik antar individu ${ }^{2,3}$. Sangat penting untuk diketahui bahwa varian genetik (polimorfisme) dapat menjelaskan terjadinya perbedaan fenotip performa atlet, oleh karena itu berbagai penelitian telah mulai dilakukan untuk menemukan hubungan antara polimormisme gen dengan performa atlet ${ }^{4}$. Berdasarkan hasil metanalisis pada 88 artikel oleh Ma et al tahun 2103 disimpulkan bahwa polimorfisme gen ACTN 3 yaitu ACTN 3 allelle $\mathrm{R}$ berhubungan signifikan dengan muscle power performance atlet sedangkan gen ACTN3 genotip XX berperan dalam muscle endurance atlet ${ }^{5}$. Berdasarkan penelitian oleh Cieszczyk, P et al tahun 2011 bahwa polimorfisme gen ACTN 3 yaitu adanya allele $\mathrm{R}$ gen ACTN 3 menunjukkan bahwa atlet pendayung profesional menunjukkan frekuensi genotip allele $\mathrm{R}$ gen ACTN 3 yang lebih tinggi dibandingkan dengan kelompok kontrol. Allele $\mathrm{R}$ gen ACTN 3 penting bagi atlet pendayung professional yang membutuhkan kontraksi otot isokinetik dan muscle power yang baik ${ }^{6}$. Hasil penelitian tersebut sejalan dengan penelitian oleh Orysiak, J tahun 2014 menemukan bahwa polimorfisme gen ACTN 3 R577X berhubungan signifikan dengan kemampuan atlet muda pria dalam menghasilkan daya ledak otot pada ekstremitas bawah ${ }^{7}$. Polimorfisme gen ACTN 3 dapat menjelaskan perbedaan muscle performance antar individu pada atlet.

\section{FUNGSI GEN ACTN 3}

Salah satu gen yang berperan dalam performa fisik manusia adalah gen ACTN 3 yang mengkode protein $\alpha$ actinin $-3^{8}$. Terdapat empat gen untuk $\alpha$ actinin yang ditemukan pada manusia yaitu ACTN 1, ACTN 2, ACTN 3 dan ACTN 4. ACTN 1 dan ACTN 4 adalah non muscle protein, sedangkan ACTN 2 dan ACTN 3 adalah myofibrilar protein yang terletak di $\mathrm{Z}$ disk. ACTN 3 adalah protien isoform spesifik fast twitch yang hanya diekpresikan pada serat otot tipe II. ${ }^{9}$ Protein ini membentuk bagian dari apparatus kontraktil (sarcomeric) fast glycolytic fibers pada otot skelet manusia. Fast glycolytic fibers berperan untuk menghasilkan kontraksi otot yang kuat dan cepat seperti pada sprint dan angkat beban. Protein $\alpha$ actinin-3 berfungsi dalam menjaga integritas mekanik otot dan kemungkinan juga berperan dalam fungsi lain berkaitan dengan metabolisme dan proses signalling pada otot ${ }^{8}$. Protein $\alpha$ actinin-3 merupakan protein yang paling spesifik diantara keempat $\alpha$ actinin pada mamalia dimana $\alpha$ actinin-3 ekspresinya terbatas pada serat otot tipe II (fast twitch) pada otot skeletal ${ }^{10,11}$. Hasil penelitian saat ini terhadap performa atlet professional menunjukkan bahwa protein $\alpha$ actinin-3 memberikan efek positif pada power performance, hal tersebut seiring dengan hasil penemuan mengenai struktur dan signaling protein $\alpha$ actinin-3 pada serat otot tipe II (fast twitch $)^{12}$. Polimorfisme pada gen ACTN 3 menyebabkan terjadinya defisiensi $\alpha$ actinin3, dimana defisiensi a actinin-3 berhubungan dengan peningkatan muscle endurance atlet maupun populasi pada umumnya ${ }^{8,13}$ sedangkan genotip homozigot gen ACTN 3 tidak menyebabkan terjadinya perubahan fenotip atau histologi otot $^{8}$. Berdasarkan hasil studi kohort oleh Papadimitriou, ID et al tahun 2007 dimana 
salah satu hasil yang ditemukan bahwa tidak ada satupun atlet sprinter tingkat Olympic Eropa yang menunjukkan genotip XX dari gen ACTN 3. Studi kohort tersebut juga menunjukkan bahwa terdapat perbedaan yang signifikan pada persentase frekuensi allele $\mathrm{R}$ antara kelompok kontrol dan kelompok power-oriented athletes sedangkan frekuensi atlet dengan genotip ACTN3 XX lebih tinggi pada kelompok endurance athlete ${ }^{12}$.

\section{POLIMORFISME GEN ACTN 3 GENOTIP RR dan RX BERHUBUNGAN DENGAN MUCSLE POWER ATLET}

Kemampuan otot skelet untuk menghasilkan kekuatan dengan kecepatan tinggi merupakan kunci pada muscle power performance seorang atlet, dimana hal tersebut dipengaruhi oleh faktor lingkungan dan genetik. Berbagai varian genetik seperti polimorfisme telah terbukti berhubungan dengan muscle power performance atlet. Salah satu gen yang berperan dalam muscle power performance adalah ACTN3. North et al tahun 1999 mengidentifikasi polimorfisme gen ACTN3 yang umum terjadi adalah pada exon 16 dari gen ACTN3 menyebabkan penggantian arginin (R) dengan stop codon prematur (X) pada asam amino 577 menyebabkan terbentuknya 3 varian gen ACTN3 yaitu genotip RR,RX,dan XX. ACTN 3 allele R berhubungan signifikan dengan power performance sedangkan ACTN3 XX berhubungan dengan endurance performance ${ }^{15}$. Berdasarkan penelitian oleh Jeremic D et al tahun 2019 menunjukkan bahwa hasil tes seven continuous vertical jumps (anaerobic power) populasi dengan genotip ACTN3 RR dan RX mencapai hasil test yang lebih baik yang signifikan dibandingkan dengan kelompok yang memiliki genotip ACTN3 $\mathrm{XX}^{16}$. Menurut penelitian oleh Yang $\mathrm{N}$ et al tahun 2003 allele $\mathrm{X}$ atau genotip ACTN3 XX berhubungan dengan endurance performance atlet ${ }^{17}$ sedangkan allele $577 \mathrm{R}$ dan genotip 577RR dari gen ACTN3 berhubungan dengan power oriented performance atlet ${ }^{18}$. Terdapat hubungan positif antara adanya allele $\mathrm{R}$ dengan kemampuan untuk melakukan kontraksi otot berenergi tinggi (high-power muscle contractions $)^{19,20}$. Berdasarkan penelitian oleh Vincent et al tahun 2007 menunjukkan bahwa persentase jumlah serat otot tipe IIx (fast twitch glycolitic) lebih besar pada genotip RR dibandingkan dengan genotip XX pada populasi pria sehat ${ }^{21}$. Variasi genotip ACTN3 RR dan RX berhubungan positif dengan kekuatan dan muscle power atlet $^{13}$ dan penggantian arginin $(\mathrm{R})$ dengan stop codon prematur (X) pada asam amino 577 menghasilkan variasi gen ACTN3 R577X yang berperan dalam power performance ${ }^{14}$. Sekitar $45 \%$ dari proporsi distribusi tipe serat otot dipengaruhi oleh faktor genetik. Gen ACTN3 R577X berperan dalam muscle power performance dengan mempengaruhi fungsi kontrol proporsi tipe serat otot. Varian gen ACTN3 merupakan salah satu gen yang berkontribusi dalam distribusi tipe serat otot melalui interaksinya dengan calcineurin ${ }^{21}$. Calcineurin merupakan serine-threonine phosphatase yang diaktivasi oleh $\mathrm{Ca}^{2+}$ calmodulin yang berperan dalam signaling pathway yang penting dalam regulasi gen dan respon biologis terhadap stimulus eksternal pada berbagai organisme dan berbagai tipe $\mathrm{sel}^{22,23}$. Signaling pathway yang melibatkan calcineurin mengontrol ekspresi gen tipe serat otot spesifik pada otot skelet. Mekanisme molekuler melalui pola yang berbeda dari aktivitas saraf motorik menyebabkan perubahan ekpresi gen serat otot slow dan fast twitch ${ }^{24}$. Hasil penelitian oleh Semsarian et al tahun 1999 menemukan 
bahwa calcineurin menyebabkan perubahan metabolisme otot skelet lebih cenderung ke metabolisme glikolitik. Hewan coba yang diinjeksi dengan IGF-1 mengaktivasi calcineurin yang memobilisasi sel satelit dan meningkatkan aktivitas enzim glycolytical dan produk akhirnya yaitu laktat. Ikatan $\alpha$ actinin-3 dengan calsarcins berinteraksi dengan calcineurin memicu pembentukan serat otot tipe fast twitch ${ }^{25}$.

\section{POLIMORFISME GEN ACTN3 GENOTIP $X X$ BERHUBUNGAN DENGAN MUSCLE ENDURANCE ATLET}

Salah satu varian gen ACTN3 karena polimorfisme yaitu terbentuknya allele $\mathrm{X}$ homozigot yang menyebabkan defisiensi $\alpha$ actinin-3. Varian gen ini sangat umum terjadi pada manusia dengan frekuensi ratarata $45 \%$ pada populasi di dunia ${ }^{26}$. Defisiensi $\alpha$-actinin-3 tidak menimbulkan penyakit tetapi mengubah fisiologi otot. Berdasarkan penelitian oleh Lucia et al tahun 2007 menemukan bahwa atlet dengan gen ACTN3 genotip XX endurance performance yang lebih baik dibandingkan dengan kelompok atlet dengan gen ACTN genotip RX dan $\mathrm{RR}^{27}$.

Berdasarkan penelitian oleh McArthur tahun 2008 menemukan bahwa gen ACTN genotip $\mathrm{XX}$ berhubungan dengan peningkatan kapasitas endurance ${ }^{28}$, pengurangan ukuran serat otot tipe fast twitch, perubahan metabolisme pada serat otot fast twitch yang lebih mengarah pada metabolisme oksidatif ${ }^{28,29}$ dan peningkatan aktifitas calcineurin signaling dan peningkatan respon terhadap endurance training. Efek dari ACTN3 knockout pada mencit mennyebabkan peningkatan aktivitas alpha-actinin 2 menyebabkan transisi tipe serat otot ke arah tipe serat otot yang fatigue resistance sebagai mekanisme kompensasi defisiensi protein ACTN3 fungsional ${ }^{30}$.

Pada individu yang memiliki gen ACTN3 genotip XX terjadi defisiensi protein $\alpha$ actinin 3 , dimana defisiensi protein $\alpha$-actinin 3 dapat mempengaruhi struktur, signaling dan calcium handling pathway serta metabolisme pada otot skeletal ${ }^{31}$. Perubahan structural otot skeletal yang terjadi akibat defisiensi protein $\alpha$-actinin 3 yaitu protein structural pada otot skeletal seperti desmin, $\gamma$-filamin, myotilin, Z-band alternatively splized PDZ motif containing protein (ZASP) mengalami upregulation. ZASP, vinculin dan titin lebih cenderung berikatan dengan $\alpha$-actinin 2 dibandingkan dengan $\alpha$ actinin 3. Perubahan signaling pada kondisi defisiensi $\alpha$-actinin 3 yaitu calsarcin 2 lebih cenderung berikatan dengan $\alpha$-actinin 2 yang menyebabkan dilepaskannya inhibisi aktivitas calcineurin sehingga terjadi peningkatan signaling calcineurin. Peningkatan signaling calcineurin menyebabkan nuclear factor of cativated $\mathrm{T}$ cell (NFAT) teraktivasi kemudian mengalami transokasi ke nucleus lalu terjadi peningkatan ekspresi gen yang mengatur metabolisme oksidatif dan slow myogenic program. Perubahan yang terjadi akibat defisiensi $\alpha$-actinin 3 adalah perubahan metabolisme pada otot skelet yaitu terjadi penurunan aktivitas enzim metabolisme anaerobik yaitu enzim lactate dehidrogenase (LDH) dan peningkatan aktivitas enzim glikolitik yaiitu hexokinase (HK), glyceraldehyde-3-phosphate dehydrogenase (GAPDH) dan juga terjadi peningkatan aktivitas enzim-enzim yang berhubungan dengan metabolisme oksidatif mitokondria dan oksidasi asam lemak (3-hydroxyacylCoA dehydrogenase/BHAD, medium chain acyl-CoA dehydrogenase/MCAD, citrate cynthase/CS, succinate dehydrogenase/SDH, cytochrome c oxidase/CCO, dan NADH tetrazoleum 
reductase/NADH-TR). Terjadi penurunan aktivitas enzim glycogen phosphorylase $(\mathrm{GPh})$ sehingga terjadi akumulasi glikogen yang lebih banyak. Perubahan yang terjadi pada calcium handling yaitu terjadi peningkatan kecepatan pelepasan kalsium $\left(\mathrm{Ca}^{2+}\right)$ dan absorbsi oleh reticulum sarkoplasma dan peningkatan sarcoplasmic reticulum calcium ATPase 1 (SERCA1) yang menggunakan ATP dan menghasilkan panas $^{31}$. Efek defisensi $\alpha$-actinin 3 pada struktur, signaling, metabolisme dan calcium handling otot skelet dapat dilihat pada gambar 1 di bawah ini.

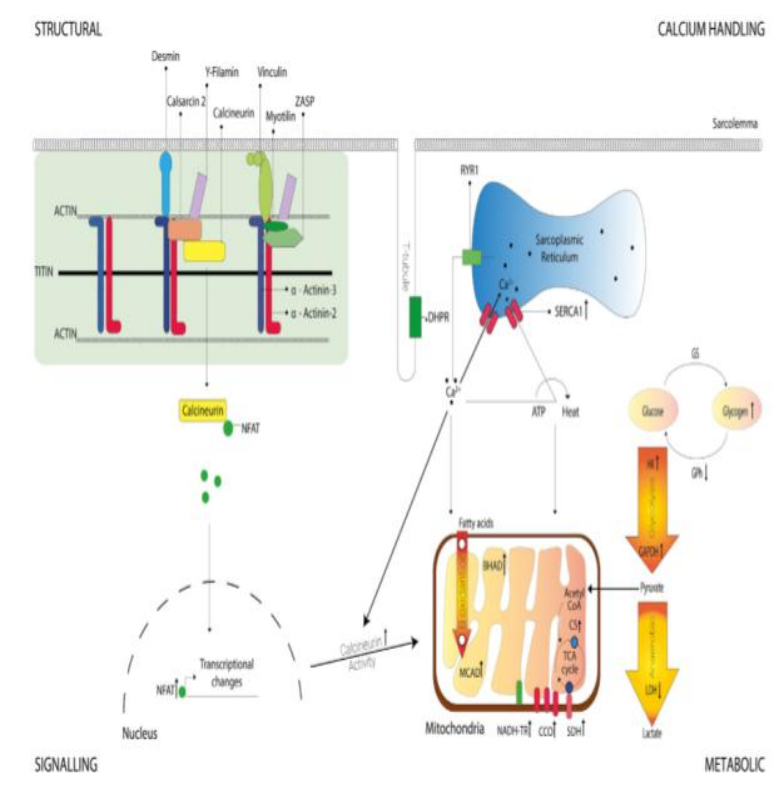

Gambar 1

Efek defisensi $\alpha$-actinin 3 pada struktur, signaling, metabolisme dan calcium handling

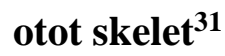

\section{SIMPULAN}

1. Gen ACTN3 merupakan salah satu gen yang berperan dalam muscle perfomance atlet.

2. Polimorfisme gen ACTN genotip RR dan $\mathrm{RX}$ berperan dalam muscle power atlet
3. Polimorfisme gen ACTN3 genotip XX berperan dalam muscle endurance atlet.

\section{DAFTAR PUSTAKA}

1. William J Kraemer and Robert U Newton. Training for Muscular Power. 2000. Scientific Principles of Sport Rehabilitation, 11(2) : 341-368.

2. Ahmetov II, Fedotovskaya ON. 2015. Current Progress in Sports Genomics. Adv Clin Chem, 70 : 247-314.

3. Hughes DC, Day SH, Ahmetov II, Williams AG. Genetics of muscle strength and power: Polygenic profile similarity limits skeletal muscle performance. 2011. J Sports Sci, 29(13) :1425-1434.

4. Sawczuk M, Maciejewska-Karłowska A, Cięszczyk P, Leońska-Duniec A. 2014. Is GNB3 C825T polymorphism associated with elite status of Polish athletes? Biol Sport, 31:21-25.

5. Ma F, Yang Y, Li X, et al. 2013. The association of sport performance with ACE and ACTN3 genetic polymorphisms: a systematic review and meta-analysis. PLoS One, 8(1):e54685.

6. Cieszczyk, P, Sawczuk, M, MaciejewskaKarlowska, A, Ficek, K. 2012. ACTN 3 R577X polymorphism in top-levelpolish rowers. Journal of Exercise and Fitness, 10 : 12-15.

7. Orysiak, J, Busko, K, Michalski, R, MazurRozycka, J, Gajewski, J, MalczewskaLenczowska, J, Sitkowski, D, Pokrywka, A. 2014. Relationship between ACTN 3 R577X polymorphism and maximal power output in elite Polish athletes. Medicina Lithuanian Universityof Helath Science, 50 : 303-308. 
8. Mills, M., N. Yang, R. Weinberger, D.L. Vander Woude, A.H. Beggs, S. Easteal, and K. North. 2001. Differential expression of the actin-binding proteins, alpha-actinin-2 and -3 , in different species: implications for the evolution of functional redundancy. Hum. Mol. Gen, 10:1335-1346.

9. Beggs AH, Byers TJ, Knoll JH, Boyce FM, Bruns GA, and Kunkel LM. 1992. Cloning and characterization of two human skeletal muscle alphaactinin genes located on chromosomes 1 and 11. J Biol Chem, 267: 9281-9288.

10. MacArthur, DG, North, KN. 2004. A gene for speed?The evolution and function of $\alpha$ actinin-3. BioEssay, 26 : 786-795.

11. Mills, M, Yang, N, Weinberger, R, Vander, WDI, Beggs, AH, Eastreal, S, North, K. 2001. Differential expression of the actinbinding proteins, alpha-actinin -2 and -3 , in different species:implications for the evolution of functional redundancy. Hum Mol Genet, 10 : 1335-1346.

12. Papadimitriou, ID, Papadopoulos, C, Kouvatsi, A, Triantaphyllidis, C. 2007. The ACTN gene in elite Greek track and fieldathletes. Sport Med, 29 : 352-355.

13.Yang,N.,MacArthur,D.G.,Gulbin,J.P.,Hahn, A.G.,Beggs,A.H., Easteal, S. and North, K. 2003. ACTN3 genotype is associated with human elite athletic performance. Am.J.Hum.Genet, 73 : 627-631.

14. Eynon, N., Hanson, E.D., Lucia, A., Houweling, P.J., Garton, F., North, K.N. and Bishop, D.J. 2013. Genes for elite power and sprint performance: ACTN3 leads the way. Sports Med, 43 : 803-817.

15. North KN, Yang N, Wattanasirichaigoon D, et al. 1999. A common nonsense mutation results in alpha-actinin-3 deficiency in the general population. Nat Genet, 21(4) :353-4.

16. Jeremic D, Macuzic IZ, Vulovic M, Stevanovic J, Radovanovic D, Varjacic V, Djordjevic D. 2019. ACE/ACTN3 genetic polymorphisms and athletic performance of female soccer players. Rev Bras Med Esporte - Vol. 25, pp 35-39. DOI: http://dx.doi.org/10.1590/1517869220192501187684 .

17. Yang N, MacArthur DG, Gulbin JP, et al. 2003. ACTN3 genotype is associated with human elite athletic performance. Am J Hum Genet, 73(3) : 627-31.

18. Niemi AK, Majamaa K. 2005. Mitochondrial DNA and ACTN3 genotypes in finnish elite endurance and sprint athletes. Eur J Hum Genet, 13 : 965-969.

19. Clarkson PN, Devaney JM, GordishDressman H, et al. 2005. ACTN3 genotype is associated with increases in muscle strength and response to resistance training in women. J Appl Physiol, 99 : 154-163.

20. Delmonico MJ, Kostek MC, Doldo MA. 2007. Alpha-actinin-3 (ACTN3) R577X polymorphism influences knee extensor peak power response to strength training in older men and women. J Gerontol A Biol Sci Med Sci, 62 : 206-212.

21. Vincent B, De Bock K, Ramaekers M, et al. 2007. ACTN 3 (R577X) genotype is associated with fiber type distribution. Physiol Genomics, 32 : 58-63.

22. Crabtree GR. 1999. Generic signals and specific outcomes: signaling through $\mathrm{Ca} 2$, calcineurin, and NF-AT. Cell, 96 : 611-614.

23. Olson EN, Sanders WR. 2000. Calcineurin signaling and muscle remodeling. Cell, 101: 689-692. 
24. Chin ER, Olson EN, Richardson JA, Yang Q, Humphries C, Shelton JM, Wu H, Zhu W, Bassel-Duby R, Sanders WR. 1998. A calcineurindependent transcriptional pathway controls skeletal muscle fiber type. Genes Dev, 12 : 2499-2509.

25. Semsarian C, Wu M, Ju Y, Marciniec T, Yeoh T, Allen DG, Harvey RP, Graham RM. 1999. Skeletal muscle hypertrophy is mediated by a Ca2dependent calcineurin signaling pathway. Nature, 400: 576-581.

26. Amorim, CE, Acuna-Alonzo V, Salzano FM, Bortolini MC, et al. 2015. Differing evolutionay histories of the ACTN3 R577X polymorphism among the major human geographic groups. Plos one, 10, e 0115449.

27. Lucia, A., et al. 2007. The 577X allele of the ACTN3 gene is associated with improved exercise capacity in women with McArdle's disease. Neuromuscul Disord, 17(8) : 603610.

28. MacArthur DG, Seto JT, Chan S, Quinlan KG, Raftery JM, Turner N, Nicholson MD, Kee AJ, Hardeman EC, Gunning PW, et al. 2008. An ACTN3 knockout mouse provide mechanistic insights into the association between alpha-actinin-3 deficiency and human athletic performance. Hum. Mol. Genet, 17 : 1076-1086.

29. Quinlan KG, Seto, JT, Turner N, Vandebrouck A, Floetenmeyer M, Macarthur DG, Raftery JM, Lek M, Yang N, Parton RG., et al. 2010. $\alpha$-actinin deficiency results in reduced glycogen phosphorylase activity and altered calcium handling in skeletal muscle. Hum. Mol. Genet, 19 : 1335-1346.

30. Seto JT, Quinlan KG, Lek M, Zheng XF, Garton F, Mac-Arthur DG, Hogarth MW, Houweling PJ, Gregorevic P, Turner N. et al. 2013. ACTN3 genotype influence muscle performance trough the regulation calcineurin signalling. J.Clin.Invest, 123 : 4255-4263.

31. Viona, XZ, Lee, Houweling PJ, North KN, Quinlan KGR. 2016. How does $\alpha$-actinin-3 deficiency alter muscle function?Mechanisctic insight into ACTN3 , the 'gene for speed'. Biochimica et Biophysica Acta, 1863 : 686-693. 